\title{
Ovarian function and pregnancy of dairy goats supplemented with pequi oil
}

Maria Letícia Rodrigues Gomes ${ }^{1}$, Vanessa Alexandre Vieira², Gabriela Liberalino Lima ${ }^{3}$, Emanuell Medeiros Vieira ${ }^{4}$, Tamiris da Cruz da Silva ${ }^{5}$, Aline Gomes de Andrade Silva ${ }^{6}$, Janiele Santos de Araújo ${ }^{7}$, Lorrane Raíssa Geraldo de Lima ${ }^{8}$, Thais Silva Siqueira Nascimento ${ }^{9}$, Felipe dos Santos Alencar ${ }^{10}$, Marcus Roberto Góes Ferreira Costa ${ }^{11}$

\author{
1, 2, 5, 7, 8, 10 Department of Animal Science, Universidade Federal do Vale do São Francisco, Petrolina-PE \\ ${ }^{4}$ Universidade Estadual de Montes Claros, Janaúba-MG \\ ${ }^{6}$ Universidade Federal de Campina Grande, Patos-PB \\ 3, 9,11 Instituto Federal de Educação, Ciência e Tecnologia do Ceará, Crato-CE \\ *Corresponding author
}

Received: 14 Oct 2020; Received in revised form: 9 Nov 2020; Accepted: 12 Nov 2020; Available online: 13 Nov 2020

\begin{abstract}
The objective of the work in question was to evaluate the ovarian function of Saanen goats supplemented with pequi oil. The experiment was carried out at the IFCE Ovine Caprinoculture vivarium, campus Crato. Eight pure Saanen goats were used, weighing an average of 1025,15 pounds, distributed in a completely randomized design with two treatments. The first treatment constituted soy oil as the lipid source and the second treatment with pequi oil. Two estrous cycles were evaluated to analyze the reproductive parameters of the females. In the first cycle, a non-castrated sheep was used as a ruffian to identify estrus, and the ovarian function was evaluated for the presence and number of follicles by ultrasound. In the second cycle, a Saanen was used in order to mate with the females. Ultrasound was performed to assess conception, fertility and prolificacy rates. The computer software SAEG 9.1 was used to analyze the values obtained. It was found that females supplemented with soybean oil stood out in comparison to goats treated with pequi oil, except for body weight, follicular diameter and body condition score, concluding that the use of pequi oil for Saanen goats it presents itself as an economically unfeasible alternative, as it has a higher acquisition value.
\end{abstract}

Keywords - Goat, estral cycle, flushing, energetic, reproduction animal.

\section{INTRODUCTION}

The Northeast region stands out from other Brazilian states in relation to the predominance of the practice of goat farming, with more than nine million goats, representing more than $90 \%$ of the national herd [8]. Dairy goat farming has been standing out in the semi-arid region of Brazil, being characterized as a profitable and viable practice mainly for small producers [6].

However, the precariousness of technical investments results in extensive or semi-intensive production as being the majority of the production systems found in the country [31], demanding from the animal good rusticity

ISSN: 2456-1878

https://dx.doi.org/10.22161/ijeab.56.1 and adaptability to the prevailing climate in the region. Among the main breeds used in dairy production, Saanen stands out. These animals are exotic in Brazil and need more intensive food handling when compared to other breeds, due to their clear coat and pink skin, which is less conducive to acclimatization in hot regions such as the semiarid [20]. Even with these characteristics, they are widely used due to the excellent milk production. However, several factors can influence this type of production, including reproductive and nutritional efficiency [15].

Nutrition plays an extremely important role in the demand for energy, protein and other vital nutrients for the productive and reproductive process of animals [32]. 
Supplementation is commonly performed aiming at increasing reproductive performance, which consists of external protein and / or energy supplementation. In goat females, lipid supplementation is found to be directly related to the ovulation rate, having been recommended at different times before the breeding season, during the season, during pregnancy, in pre and postpartum [18] and can be strategically effective in increasing the energy density of the diet of ruminant females.

The supply of a diet rich in lipids abundant in linolenic and linoleic unsaturated fatty acids increases the process of gluconeogenesis by raising propionate in the fermentation chamber, thereby stimulating insulin secretion, modulating follicle growth, oocyte maturation and embryo development [10].

With insulin secretion and through its action, gonadotropin-releasing hormone $(\mathrm{GnRH})$ is released and secretes follicle stimulating hormone (FSH), luteinizing hormone (LH) and progesterone which in turn regulate ovarian activity and pregnancy, respectively [13].

For [18] supplementation rich in vegetable oils that has linoleic and linolenic acids in its composition, propels the process of gluconeogenesis by the influence of the increase of propionate produced, stimulating insulin and this in turn, modulates the growth of follicles, as it acts on regulation of the synthesis of gonadotropin-releasing hormone $(\mathrm{GnRH})$ neurotransmitters; oocyte maturation in the sense that it controls the release of luteinizing hormone by the pituitary gland; and embryonic development.

In Brazil, due to its great biodiversity, there is a huge variety of vegetable oils extracted from fruits of endemic and regional species, such as pequi oil. The pequizeiro (Caryocar coriaceum) occurs in the semi-arid Northeast, commonly in the cariri from Ceará and Piauí. The pequi pulp is abundant in lipids, with more than $30 \%$ in its composition [14]. There are several studies on the use of pequi oil in the manufacture of natural medicines for animals and humans $[24 ; 21 ; 23]$. However, its use in animal supplementation is scarce, with few studies as a lipid source [25] and offspring of rats [19].

Pequi oil is a product rich in unsaturated fatty acids. Palmitic and oleic fatty acids are found in abundance in the pequi pulp [9; 14], with $41.1 \%$ and $54 \%$, respectively. It is also composed of myristic $(0.2 \%)$, palmitoleic $(0.5 \%)$, stearic $(1.9 \%)$, linoleic $(1 \%)$ and linolenic $(0.3 \%)$ acids in smaller quantities [7]. Studies show that these acids can interfere in the synthesis of steroids [33], serving as important precursors for the transition from the stage of cows luteogenesis [4].
In addition, in pequi oil there are phenolic compounds, being found in greater amounts in the peel (pericarp) that guarantee the fruit the role they play as antioxidants [35], together with carotenoids. Antioxidants are extremely important in reproduction, because in their absence, there will be a greater amount of free radicals, consequently causing oxidative stress causing deleterious effects on the female reproductive system, affecting from the oocyte maturation process until pregnancy [29].

Thus, the general objective of this work was to evaluate the effect of pequi oil as a lipid supplementation inserted in the concentrated food, on the performance and reproductive parameters of goats.

\section{METHOD}

The experiment was carried out at the Federal Institute of Education, Science and Technology, Campus Crato-CE, in the Ovinocaprinoculture production sector between May and July 2018, located by geographic coordinates: latitude $7^{\circ} 12$ '43 "S and longitude $39^{\circ} 26^{\prime} 35^{\prime \prime} \mathrm{W}$ and an altitude of $542 \mathrm{~m}$. This research was submitted to evaluation and approved by the IFCE Animal Use Ethics Committee, under protocol CEUA No. 4828200418.

Eight adult Saanen goats were used, with an average age of three years, with an average weighing an average of 1025,15 pounds and empty, with fertility proven through previous births. The animals were kept on the premises for a period of 15 days for prior adaptation. The goats were kept throughout the day in paddock irrigated by sprinkling and cultivated with Tifton 85 grass (Cynodon dactylon). At the end of the day, the animals were collected and contained with access to individual troughs, where the concentrate with supplementation was provided, totaling 90 days of the experimental period.

To evaluate the effect of supplementation with pequi oil on performance and reproductive parameters, the goats were divided into two groups, each group containing four animals. The control group consisted of females supplemented with soy bran-based concentrate (3\%), ground corn grain $(87 \%)$, urea (1\%), mineral (2\%) soybean oil $(7 \%)$ and Caprinophos (Tortuga $\left.{ }^{\circledR}\right)$. For the test group, the goats received the concentrate similar to the control group, differing from the vegetable oil used, which in this group was pequi oil (7\%). During the supplementation period, the goats received a daily supply of $400 \mathrm{~g}$ of concentrate formulated based on the recommendations of nutritional requirements of the [17] for empty goats in the breeding season. The goats were identified by means of numbers attached to the ear and for better distance 
observation, ribbons with different colors were placed around the neck.

The females were weighed weekly and the body condition score was assessed through visual assessment and palpation of the transverse and spinal apophyses. Fifteen days after the start of supplying the supplements, the goats were accompanied by an adult male sheep, not castrated, for the purpose of breeding. After acceptance of the mount by all females, ultrasound was performed on them on the day or the next day, to observe the number of follicles present and their diameter, implying knowing the influence that lipid supplementation was having on these animals.

At the beginning of the second estrous cycle, the females continued to be accompanied by an adult goat breeder of the Saanen breed, in order to allow the breeding, monitoring of the ovarian follicles as described for the first cycle. After thirty days of mating, a gestational diagnosis and evaluation of the functional corpus luteum was performed for all females. The reproductive efficiency of the goats was evaluated based on the pregnancy rate, fertility and prolificacy, where the pregnancy rate was obtained through the ratio of the number of positive diagnoses and the number of diagnoses performed.

The evaluation by means of ultrasonography was performed with a linear multifrequency probe, on the white line, in front of and close to the mammary gland, after a previous fast of at least 24 hours. The device used for ultrasound was the Mindray 3.300 Vet. The frequency used was $7.5 \mathrm{MhZ}$ (megahetz), as shown in figure 1 .

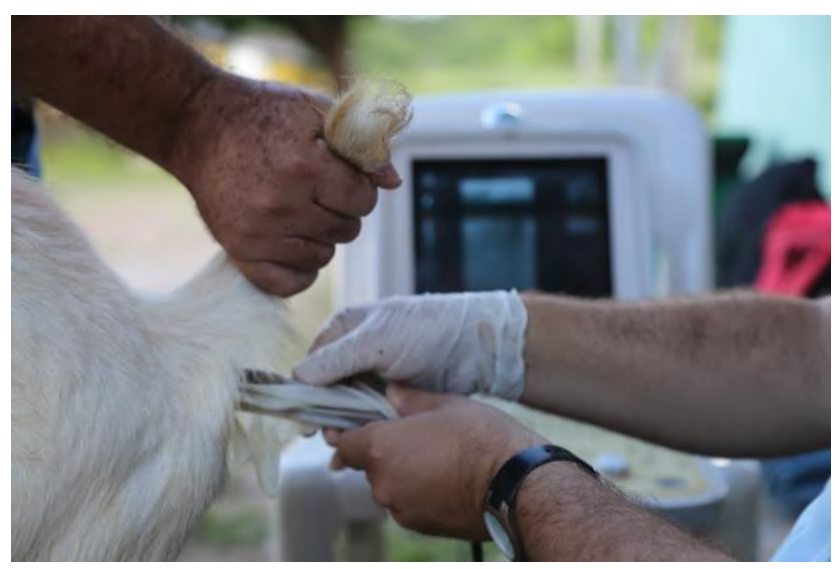

Fig.1: Ultrasonography with linear multifrequency probe to observe the number and diameter of follicles and to evaluate the corpus luteum

Source: Geo Brasil (2018)

The experiment was conducted in a completely randomized design with two treatments and four replications and the results obtained were subjected to analysis of variance and those that showed significance were subjected to the Tuckey test, with 5\% significance, to compare the means using the package computational System for Statistical Analysis - SAEG 9.X.

\section{RESULTS AND DISCUSSIONS}

The goats that received pequi oil supplementation had a larger follicular diameter compared to the control treatment. Table 1 shows that the body weight of goats treated with the lipid supplementation of pequi oil stood out from the control treatment goats, which influences their body condition score index, that is, these goats had a greater amount of fat and muscles in bone structures.

Table 1. Zootechnical indexes of the goats according to their respective treatments.

\begin{tabular}{lccc}
\hline & $\begin{array}{c}\text { Body } \\
\text { weight }(\mathrm{kg})\end{array}$ & $\begin{array}{c}\text { Body condition } \\
\text { score }\end{array}$ & $\begin{array}{c}\text { Follicular } \\
\text { Diameter }(\mathrm{mm})\end{array}$ \\
\hline $\begin{array}{l}\text { Pequi } \\
\text { Oil }\end{array}$ & 41,48 & 2,4 & 14,47 \\
$\begin{array}{l}\text { Soy } \\
\text { oil }\end{array}$ & 36,28 & 2,3 & 11,07 \\
\hline
\end{tabular}

Source: Author (2018)

The increase in ovulation rate and prolificacy are dependent on an agile increase in the animal's body condition score. Supplementation provides this increase, since the moment before the breeding it is necessary to provide the animal with a supplementation of nutrients that improve its reproductive capacity, as well as its body conditions, which is one of the aspects that causes a benefit in reproduction [22].

The increase in the body condition score refers to the consumption of energy diets, causing a reduction in the concentration of insulin that minimizes the entry of glucose into the cell, causing a decrease in the steroid hormones that modify the quality of the oocyte, namely progesterone and estradiol. , also changing follicle growth and embryo viability [36].

In a study by [16] goats receiving high energy concentrated supplementation had a positive increase in body weight during pregnancy and reproductive performance, concluding that low weight and consequently low body condition score can affect fertility. For [1] the body condition score is an important practical methodology in the management of high production dairy animals, as they need adequate body reserve for energy and protein requirements during the beginning of lactation. 
It was observed that for the treatment with pequi oil the follicular diameter was larger. Follicular diameter is directly related to the diameter of the oocyte and its competence in embryonic development [26]. The diameter is also related to the estradiol concentration rates and its increase is linked to the probability of ovulation and conception rate, being directly related to the corpus luteum in the final formation process. The corpus luteum of reduced volume is due to the formation of smaller follicles, strongly influencing less development of the embryo and as a consequence, low fertility.

For [27], linoleic and linolenic polyunsaturated fatty acids are important for fertility, as they affect follicle size, oocyte quality and corpus luteum size. This is because they have an effect on the concentration of steroid hormones and prostaglandins.

In a study with beef heifers supplemented with soybean oil it was observed that the quantity and diameter of the follicles increased [34]. These results are similar to those found in this study, according to the ovarian indices.

In studies by [12] with goats supplemented with soybean oil and barley, obtained as a result that these dietary lipid compounds increased the levels of progesterone in the blood during the period of ovulation and post-ovulation. According to research by [11], soybean oil is composed of the mystic fatty acids $(<0.5)$, palmitic (7.0-14.0), stearic (1.4-5.5), linolenic (4.0-11, 0) oleic (19.0-30.0) and linoleic (44.0-62.0), the latter two being characterized as more abundant. However, soy is rich in phytoestrogen, similar to the hormone estrogen and that mimics its functions, binding to its receptors.

For the control treatment, a larger amount of follicles was observed in a higher number of animals compared to the treatment with pequi oil. Table 2 shows the treatments according to the supplementation of the goats in the two estrous cycles. For the evaluated parameters, it is possible to highlight the beneficial effect that the pequi oil caused on the ovarian function.

\begin{tabular}{ccccccc}
$\begin{array}{c}\text { Table 2. Number of follicles and embryos in Saanen goats } \\
\text { supplemented with concentrate containing pequi oil or } \\
\text { soybean oil, according to the EC (estrous cycles). }\end{array}$ \\
\hline \multirow{2}{*}{$\begin{array}{c}\text { Treatment } \\
\text { Parameter }\end{array}$} & \begin{tabular}{c} 
Animal \\
\cline { 3 - 6 }
\end{tabular} & A & B & C & D & Média \\
\hline $1^{\circ}$ EC Pequi oil & $\begin{array}{c}\text { Number of } \\
\text { embryos }\end{array}$ & 3 & 1 & 1 & 1 & $1,5 \mathrm{~b}$ \\
\hline $1^{\circ}$ EC Soy oil & $\begin{array}{c}\text { Number of } \\
\text { embryos }\end{array}$ & 4 & 4 & 5 & 1 & $3,5 \mathrm{a}$
\end{tabular}

\begin{tabular}{lcllllll}
\hline $2^{\circ}$ EC equi oil & $\begin{array}{c}\text { Number of } \\
\text { embryos }\end{array}$ & 0 & 1 & 1 & 1 & $0,75 b$ \\
\hline $2^{\circ}$ EC Soy oil & $\begin{array}{c}\text { Number of } \\
\text { embryos }\end{array}$ & 3 & 2 & 1 & 1 & $1,75 \mathrm{a}$ \\
\hline
\end{tabular}

* Lowercase letters compare averages in the column. Means followed by different letters differ from each other by Tukey's test at $5 \%$ significance.

Source: Author (2018).

In the first estrous cycle, the number of follicles for each treatment differed statistically, as well as for the number of embryos in the second estrous cycle, being higher in goats that received soy oil as a lipid supplement in the concentrate.

For [28], the brief supplementation that contains in the high energy capacity diet, simultaneously with the estrus synchronization, provides an increase in estrous activity, increasing the performance in sheep reproduction. In a study by the same authors, the objective was to assess whether supplementation, that is, a short-term high-energy diet, has any overstimulating effect on ovarian function in sheep, with the conclusion that supplementation improved estrus expression and ovarian activity .

The positive results in the zootechnical indexes in the test treatment with pequi oil may be due to components present in the oil of this fruit, such as the antioxidants that cause the balance of free radicals, which can generate negative changes in the maturation and fertilization processes of the oocytes.

The role of fatty acids on the quality of the embryo and concentration of levels of steroid hormones and prostaglandins proved their influence on the ovarian function of bovine females. Soy oil is abundant in linoleic and linolenic acids.

They obtained as a result that for the variables of superovulation, embryonic recovery rate and embryonic quality there was no significant difference, but even with the increase in polyunsaturated fatty acids, the production of arachidonic acid, which is a precursor of prostaglandins, decreased - an increase in prostaglandin production is expected, making the environment more luteotrophic, with the exception of a reduced number of degenerate embryos after supplementation with n-3 (polyunsaturated FA).

In research by [3] using sources of vegetable oils, sunflower and flaxseed, it was observed that polyunsaturated fatty acids had beneficial effects on the size of the ovarian follicles, as well as on the size of the corpus luteum. 
According to previous information, it is known that linoleic and linolenic polyunsaturated fatty acids have an unquestionable role in reproduction, since they serve as precursors for processes that increase the energy density of the ruminant, influencing its ovarian function. Soy oil has these fatty acids in greater abundance when compared to pequi oil, with much lower percentages for the latter, which may hypothetically have influenced that the treatment with soy oil has positively excelled in the parameters of fertility, prolificacy and conception.

The amount to be used in the concentrate is also a major factor in terms of its functionality, however, the excess (above $7 \%$ ) of fat can decrease the digestion of fiber by the ruminant, since there is the covering of its particles, preventing it from being degraded by microorganisms, negatively influencing the proportions of short-chain fatty acids to be produced in the rumen [30]. According to these authors, there is a reduction in insulin concentration and stimulation of body fat mobilization

However, factors such as degree of saturation, form of inclusion of the lipid source in the diet and length of the chain are preponderant in the responses of the animals [18].

\section{CONCLUSIONS}

Although in the zootechnical parameters of body condition score and ovarian follicular diameter the animals have benefited more with lipid supplementation in comparation with pequi oil, for the other indexes the treatment with soybean oil obtained a higher value in the ovarian function of Saanen dairy goats.

The use of Pequi oil can become an economically unviable alternative based on the results obtained in this work, with the current reality being the greater use of soy oil, in addition to being easily found and having a lower purchasing value.

Because research related to the use of pequi oil in the ovarian function of ruminants is non-existent and vegetable oils are scarce, other studies should be conducted with a larger number of animals, as well as with other breeds and / or crosses to consolidate the results here reported. As well as the type of management (confined or grazed) can interfere in the results.

\section{REFERENCES}

[1] BARBOSA, L. P. Et al. Condição corporal e desempenho produtivo de cabras Alpinas no início de lactação. Revista Brasileira de Zootecnia, [s.1.], v. 38, n.
11, p. 2137-2143, nov. 2009. FapUNIFESP (SciELO). http://dx.doi.org/10.1590/s1516-35982009001100010.

[2] BEZERRA, N.K.M.S.; BARROS, T.L.; COELHO,

N.P.M.F. A ação do óleo de pequi (Caryocar brasiliense) no processo cicatricial de lesões cutâneas em ratos. Revista Brasileira de Plantas Medicinais, [s.l.], v. 17 , n. 42 , p. $875-880$, 2015. FapUNIFESP (SciELO). http://dx.doi.org/10.1590/1983-084x/14_061.

[3] BILBY, T.R. et al. Effects of Dietary Unsaturated Fatty Acids on Oocyte Quality and Follicular Development in Lactating Dairy Cows in Summer. Journal Of Dairy Science, [s.1.], v. 89, n. 10, p. 3891-3903, out. 2006. American Dairy Science Association. http://dx.doi.org/10.3168/jds.s0022-0302(06)72432-8.

[4] BRITO NETO, E. P. Diâmetro de folículo maior no momento da aplicação de estradiol e taxa de gestação em vacas submetidas à sincronização da ovulação para iatf. 2012. 69 f. Dissertação (Mestrado) - Curso de PÓs-graduaÇÃo em Medicina VeterinÁria, Universidade Federal de Viçosa, Viçosa - Mg, 2012.

[5] CHILDS, S. et al. Embryo yield and quality following dietary supplementation of beef heifers with n-3 polyunsaturated fatty acids (PUFA). Theriogenology, [s.1.], v. 70, n. 6, p. 992-1003, out. 2008. Elsevier BV. http://dx.doi.org/10.1016/j.theriogenology.2008.06.008.

[6] CRUZ, G. R. B. da. Et al. Estimativas de parâmetros genéticos e de ambiente para medidas repetidas de produção leiteira em caprinos. Ciência Animal Brasileira, [s.1.], v. 20, p. 1-13, 2019. FapUNIFESP (SciELO). http://dx.doi.org/10.1590/1089-6891v20e47704.

[7] DEUS, T. N. de. Extração e caracterização de óleo do pequi (Caryocar brasiliensis Camb.) para o uso sustentável em formulações cosméticas óleo/água (O/A). 2008. 75 f. Dissertação (Mestrado) - Curso de Ecologia e Produção Sustentável., Universidade Católica de Goiás, Goiânia, 2008.

[8] FARIAS, A. M. et al. Soroprevalência da infecção por Corynebacterium pseudotuberulosis em caprinos no Nordeste brasileiro utilizando técnica de imunoabsorção enzimática (ELISA-indireto). Pesquisa Veterinária Brasileira, [s.1.], v. 38, n. 7, p. 1344-1350, jul. 2018. FapUNIFESP (SciELO). http://dx.doi.org/10.1590/16785150-pvb-5282.

[9] GARCIA, C. C. et al. Thermal stability studies of some cerrado plant oils. Journal Of Thermal Analysis And Calorimetry, [s.1.], v. 87, n. 3, p. 645-648, mar. 2007. Springer Science and Business Media LLC. http://dx.doi.org/10.1007/s10973-006-7769-x.

[10] GRESSLER, M. A. L.; SOUZA, M.I. L. Efeitos da suplementação com gordura protegida sobre uma foliculogênese ovariana de ruminantes. Veterinária e Zootecnia, [S.I], v. 3, n. 2, p. 70-79, jun. 2009.

[11] ISSARIYAKUL, T.; DALAI, A. K.. Biodiesel from vegetable oils. Renewable And Sustainable Energy Reviews, [s.1.], v. 31, p. 446-471, mar. 2014. Elsevier BV. http://dx.doi.org/10.1016/j.rser.2013.11.001. 
[12] KIA, H. D. Et al. Effects of suplementação and hormonal treatment on reproductive performance of Iranian Markhoz goats. Journal Of Animal Physiology And Animal Nutrition, [s.1.], v. 96, n. 6, p. 1157-1164, 4 out. 2011. Wiley. http://dx.doi.org/10.1111/j.14390396.2011.01234.x.

[13] KRASNOW, S; STEINER, R. Physiological Mechanisms Integrating Metabolism and Reproduction. Knobil And Neill's Physiology Of Reproduction, [s.1.], 3. Ed. p. 2553-2625, 2006.2 Elsevier. http://dx.doi.org/10.1016/b978-012515400-0/50052-x.

[14] LIMA, A. de. et al. Composição química e compostos bioativos presentes na polpa e na amêndoa do pequi (Caryocar brasiliense, Camb.). Revista Brasileira de Fruticultura, [s.1.], v. 29, n. 3, p. 695-698, 2007. FapUNIFESP (SciELO). http://dx.doi.org/10.1590/s010029452007000300052.

[15] MAIA, A. L. R. e S. et al. Distúrbios reprodutivos em cabras leiteiras e impactos potenciais nos sistemas de produção. Revista Acadêmica: Ciência Animal, [s.l.], v. 15, n. 2, p. 77-89, 29 ago. 2017. Pontificia Universidade Catolica do Parana - PUCPR. http://dx.doi.org/10.7213/academica.15.s02.2017.a08.

[16 MELLADO, M.. Et al. Short communication: reproductive response to concentrate supplementation of mixed-breed goats on rangeland. : Reproductive response to concentrate supplementation of mixed-breed goats on rangeland. Tropical Animal Health And Production, [s.1.], v. 52, Bp. 1-5, 21 mar. 2020. Springer Science and Business Media LLC. http://dx.doi.org/10.1007/s11250020-02264-Z.

[17] NOCITI, Mv. Msc. Ricardo P. et al. Efeito da ingestão de lipídeos sobre a reprodução de pequenos ruminantes: revisão de literatura. Investigação Medicina Veterinária, São Paulo, v. 4, n. 15, p.42-46, 2016.

[18] NATIONAL RESEARCH COUNCIL - NRC. Nutrient requirements of small ruminants. 2007, 362p.

[19] OLIVEIRA, M. L. de A.. Avaliação dos parâmetros ansiolíticos em prole de ratas wistar suplementadas com óleo de pequi (caryocar brasiliense camb) durante a gestação e lactação. 2019. 43 f. TCC (Graduação) - Curso de Nutrição, Universidade Federal de Campina Grande, Cuité - Paraíba, 2019.

[20] PAUlO, J. L. de A.; LOPES, F. de A.. Daily activity patterns of Saanen goats in the semi-arid northeast of Brazil. Revista Brasileira de Zootecnia, [s.1.], v. 43, n. 9, p. 464-470, set. 2014. FapUNIFESP (SciELO). http://dx.doi.org/10.1590/s1516-35982014000900002.

[21] POZO, O. V. C. O pequi (caryocar brasiliensé): uma alternativa para o desenvolvimento sustentável do cerrado no norte de minas gerais. 1997. $100 \mathrm{f}$. Dissertação (Mestrado) - Curso de Mestrado em Administração Rural, Universidade Federalde Lavras, Lavras - Mg, 1997.

[22] RANGEL, C. C. Ação da própolis no perfil metabólico de ovelhas em fase reprodutiva. 2013. 76 f. Dissertação (Mestrado) - Curso de Ciências Veterinárias,
Universidade Federal do Espírito Santo, Alegre - Es, 2013.

[23] REDA, S. Y.; CARNEIRO, P.I B. óleos e gorduras: aplicações e implicações. Revista Analytica, São Paulo, v. 27 , p. 60-67, mar. 2007.

[24] RIBEIRO, M. C. Óleo de pequi: qualidade físicoquímica, teor de carotenoides e uso em animais com carência de vitamina A. 2010. 85 f. Tese (Doutorado) Curso de Universidade Federal de Lavras, Pós-graduação em Ciência dos Alimentos, Lavras - Mg, 2010.

[25] ROCHA, A. S. da. Óleo de pequi (caryocar brasiliense, camb) na alimentação de juvenis de tambaqui (colossoma macropomum, curvier 1818). 2018. $78 \mathrm{f}$. Tese (Doutorado) - Curso de Doutorado em CiÊncias Animais, Universidade de Brasília, Brasília - Df, 2018.

[26] ROMAGUERA, R. et al. 2010. Effect of follicle diameter on oocyte apoptosis, embryo development and chromosomal ploidy in prepubertal goats. Theriogenology 74: 364-373.

[27] SARTORI, R.; GUARDIEIRO, M. M. Fatores nutricionais associados à reprodução da fêmea bovina. Revista Brasileira de Zootecnia, [s.1.], v. 39, n. , p. 422-432, jul. 2010. FapUNIFESP (SciELO). http://dx.doi.org/10.1590/s1516-35982010001300047.

[28] SENOSY, W.; MAHMOUD, G.B.; ABDEL-RAHEEM, SH. M. Influence of short-term energy supplementation on estrus, ovarian activity, and blood biochemistry in Ossimi ewes synchronized with fluorogestone acetate in the subtropics. Theriogenology, [s.1.], v. 88, p. 152-157, jan. 2017.2 Elsevier BV. http://dx.doi.org/10.1016/j.theriogenology.2016.09.027.

[29] SILVA, L. M. Et al. Importância da utilização de ácido alfa lipóico (ALA) e catalase (CAT) no processo de criopreservação de folículos ovarianos pré-antrais, visando reduzir os danos causados pelo estresse oxidativo. Revista de Medicina da Ufc, [s.1.], v. 60, n. 1, p. 41-46, 30 mar. 2020. Revista de Medicina da UFC. http://dx.doi.org/10.20513/2447-6595.2020v60n1p41-46.

[30] SILVA, M. M. C. da. Et al. Efeito da suplementação de lipídios sobre a digestibilidade e os parâmetros da fermentação ruminal em cabras leiteiras. Revista Brasileira de Zootecnia, [s.1.], v. 36, n. 1, p. 246-256, fev. 2007. FapUNIFESP (SciELO). http://dx.doi.org/10.1590/s1516-35982007000100029.

[31] SILVA, W. E. Et al. Organic and conventional management in a Parda Alpina dairy goat production system in northeastern Brazil. Semina: Ciências Agrárias, [s.1.], v. 36, n. 5, p. 3189-3202, 21 out. 2015. Universidade Estadual de Londrina. http://dx.doi.org/10.5433/1679-0359.2015v36n5p3189

[32] SILVA, V. L. et al. Importância da nutrição enérgetica e proteica sobre a reprodução em ruminantes. Acta Kariri Pesq. e Des, Crato-ce, v. 1, n. 1, p. 38-47, nov. 2016.

[33] THOMAS, M G; BAO, B; WILLIAMS, G L. Dietary fats varying in their fatty acid composition differentially influence follicular growth in cows fed isoenergetic diets. Journal Of Animal Science, [s.1.], v. 75, n. 9, p. 
2512-2519, 1997. Oxford University Press (OUP).

http://dx.doi.org/10.2527/1997.7592512x.

[34] THOMAS, M.g.; WILLIAMS, G.1.. Metabolic hormone secretion and FSH-induced superovulatory responses of beef heifers fed dietary fat supplements containing predominantly saturated or polyunsaturated fatty acids. Theriogenology, [s.1.], v. 45, n. 2, p. 451-458, jan. 1996. Elsevier BV. http://dx.doi.org/10.1016/0093691x(95)00381-h.

[35] VALE, A. F. et al. Antioxidant effect of the pequi oil (Caryocar brasiliense) on the hepatic tissue of rats trained by exhaustive swimming exercises. Brazilian Journal Of Biology, [s.1.], v. 79, n. 2, p. 257-262, abr. 2019. FapUNIFESP (SciELO). http://dx.doi.org/10.1590/15196984.180015.

[36] WESCHENFELDER, M. M. Metabolismo energético, resistência a insulina e produção de leite durante o periparto de vacas leiteiras com diferentes concentrações de bPL. 2013. 43 f. Dissertação (Mestrado) - Curso de Pós-graduação em Veterinária, Universidade Federal de Pelotas, Pelotas, 2013. 